\title{
Dysfunction of Maternal Thyroid Hormones and Psychiatric Symptoms
}

\author{
Ahmed R.G. \\ Division of Anatomy and Embryology, Zoology Department, Faculty of Science \\ Beni-Suef University, Beni-Suef, Egypt \\ ahmedragab08@gmail.com
}

\section{COMMENTARY}

The steady in the functions of gestational thyroid hormones (THs) displays major actions in the developing brain in particular the development and differentiation of neurons, oligodendrocytes, astrocytes and microglial cells(El-bakry et al., 2010; Ahmed, 2011, 2012a,b, 2013, 2014, 2015a-c, 2016a-d, 2017a-u \& 2018a,b; Ahmed et al., 2010, 2013a,b, 2014, 2015a,b \&2018a,b; Ahmed and Incerpi, 2013;Van Hercket al., 2013; Ahmed and ElGareib, 2014, Incerpi et al., 2014; Candelotti et al., 2015; De Vito et al., 2015; El-Ghareeb et al., 2016; Ahmed and El-Gareib, 2017; Moog et al., 2017).

On the other hand, in the developing or mature central nervous system (CNS), any deviations in the activities of THs (hypothyroidism or hyperthyroidism) can impair the development and function of the neurons and microglial cells (an immune cell population in the CNS) (Duntas and Maillis, 2013; Noda, 2015). These impairments might increase the risk of mental/psychiatric disorders (neurological and behavioral defects) including depression, schizophrenia, spasticity, anxiety, bipolar disorder, and ataxia (Thompson and Potter, 2000; Noda, 2015). In addition, these changes are irreversible and permanent (Di Liegro, 2008; Henrichs et al., 2010; Noda, 2015). More importantly, there are several psychiatric symptoms during the hypothyroidism such as anergia, psychosis, mania, apathy, mood instability, hypersomnia, dementia (Osterweil et al., 1992; Goh et al., 2014), attentional abnormalities and delaying the psychomotor (Awad, 2000). These symptoms with the cognitive impairment might be increased with the age progress (Mallett et al., 1995; Dugbartey, 1998). On the other hand, there are other psychiatric symptoms during the hyperthyroidism such as depression and anxiety (Demet et al., 2002), abnormalities in the appetite and sleep, emotional lability, exaggerated sensitivity to noise, distractible overactivity, and impatience or irritability (Awad, 2000). Additionally, in the elderly, Alzheimer's disease (AD), dementia, and cognitive defects were observed in the subclinical hyperthyroidism (Kalmijn et al., 2000; van Osch et al., 2004; Wijsman et al., 2013). From the previous results, it can be inferred that the hyperthyroidism or hypothyroidism may elevate the possibility of neurodegeneration and cognitive defects. These changes can be attributed to the effect of thyroid disorders (hyperthyroidism or hypothyroidism) on the immune system. Hypothyroidism can cause several abnormalities as the following (Klecha et al., 2000 \& 2006; De Vito et al., 2011): (1) increase the levels of reactive oxygen species (ROS); (2) augmentation of phagocytosis; (3) elevate the activities of the proinflammatory markers such as interleukin- $1 \beta$ and macrophage inflammatory protein-1 $\alpha$; (4) decrease the activities of the antioxidant enzymes; (5) reduce the lymphocyte proliferation parameters; (6) diminish the cell migration and the production of antibody; and (7) decrease the immune response. As well, hyperthyroidism can reduce the activities of the proinflammatory markers such as monocytes and macrophages (Klecha et al., 2008; De Vito et al., 2012). According these reports, it is probable that indirect roles of THs via glial cells are significant for the activity of neuronal cells and their defects may at least in part, cause several psychiatric symptoms (Noda, 2015). 
Dysfunction of Maternal Thyroid Hormones and Psychiatric Symptoms

Based on the above suggestions, the regulation in the maternal hypothalamus-pituitary-thyroid axis(HPTA) displays vital actions during the development of CNS. In addition, the dysregulations in the activities of maternal THs (hypothyroidism or hyperthyroidism) may interrupt the development of CNS and cause persistent neural disorders, mental retardation, and several psychiatric symptoms. Additional studies are required to elucidate the interactions between, thyroid dysfunctions, microglia, and neuropsychological disorders.

\section{REFERENCES}

Ahmed, O.M., Abd El-Tawab, S.M., Ahmed, R.G., 2010. Effects of experimentally induced maternal hypothyroidism and hyperthyroidism on the development of rat offspring: I- The development of the thyroid hormones-neurotransmitters and adenosinergic system interactions. Int. J. Dev. Neurosci. 28, 437-454.

Ahmed, O.M., Abd El-Tawab, S.M.,Ahmed, R.G., 2010. Effects of experimentally induced maternal hypothyroidism and hyperthyroidism on the development of rat offspring: I- The development of the thyroid hormones-neurotransmitters and adenosinergic system interactions.Int. J. Dev. Neurosci. 28, 437-454.

Ahmed, O.M., Ahmed, R.G., 2012. Hypothyroidism. In A New Look At Hypothyroidism. Dr. D. Springer (Ed.), ISBN:978-953-51-0020-1), In Tech Open Access Publisher, Chapter 1, pp. 1-20.

Ahmed, O.M., Ahmed, R.G., El-Gareib, A.W., El-Bakry, A.M., Abd El-Tawaba, S.M., 2012. Effects of experimentally induced maternal hypothyroidism and hyperthyroidism on the development of rat offspring: II-The developmental pattern of neurons in relation to oxidative stress and antioxidant defense system. Int. J. Dev. Neurosci. 30, 517-537.

Ahmed, O.M., El-Gareib, A.W., El-bakry, A.M., Abd El-Tawab, S.M., Ahmed, R.G., 2008. Thyroid hormones states and brain development interactions. Int. J. Dev. Neurosci. 26(2), 147-209. Review.

Ahmed, R.G., 2011. Perinatal 2, 3, 7, 8-tetrachlorodibenzo-p-dioxin exposure alters developmental neuroendocrine system. Food Chem. Toxicology, 49, 1276-1284.

Ahmed, R.G., 2012a. Maternal-newborn thyroid dysfunction.In the Developmental Neuroendocrinology, pp. 1-369. Ed R.G. Ahmed. Germany: LAP LAMBERT Academic Publishing GmbH \& Co KG.

Ahmed, R.G., 2012b. Maternal-fetal thyroid interactions, Thyroid Hormone, Dr. N.K. Agrawal (Ed.), ISBN: 978-953-51-0678-4, In Tech Open Access Publisher, Chapter 5, pp. 125-156.

Ahmed, R.G., 2013. Early weaning PCB 95 exposure alters the neonatal endocrine system: thyroid adipokine dysfunction. J. Endocrinol. 219 (3), 205-215.

Ahmed, R.G., 2014. Editorial: Do PCBs modify the thyroid-adipokine axis during development? Annals Thyroid Res. 1(1), 11-12.

Ahmed, R.G., 2015a. Chapter 1: Hypothyroidism and brain development. In advances in hypothyroidism treatment. Avid Science Borsigstr. 9, 10115 Berlin, Berlin, Germany. Avid Science Publications level 6, Melange Towers, Wing a, Hitec City, Hyderabad, Telangana, India. pp. 1-40.

Ahmed, R.G., 2015b. Hypothyroidism and brain developmental players. Thyroid Research J. 8(2), 1-12.

Ahmed, R.G., 2015c. Editorials and Commentary: Maternofetal thyroid action and brain development. J. of Advances in Biology; 7(1), 1207-1213.

Ahmed, R.G., 2016a. Gestational dexamethasone alters fetal neuroendocrine axis. Toxicology Letters, 258, 46-54.

American Research Journal of Endocrinology

Page 32 
Dysfunction of Maternal Thyroid Hormones and Psychiatric Symptoms

Ahmed, R.G., 2016b. Neonatal polychlorinated biphenyls-induced endocrine dysfunction. Ann. Thyroid. Res. 2 (1), 34-35.

Ahmed, R.G., 2016c. Maternal iodine deficiency and brain disorders. Endocrinol. Metab. Syndr. 5, 223.http:// dx.doi.org/10.4172/2161-1017.1000223.

Ahmed, R.G., 2016d. Maternal bisphenol A alters fetal endocrine system: Thyroid adipokine dysfunction. Food Chem. Toxicology, 95, 168-174.

Ahmed, R.G., 2017a. Developmental thyroid diseases and GABAergic dysfunction. EC Neurology 8.1, 02-04.

Ahmed, R.G., 2017b. Hyperthyroidism and developmental dysfunction. Arch Med. 9, 4.

Ahmed, R.G., 2017c. Anti-thyroid drugs may be at higher risk for perinatal thyroid disease. EC Pharmacology and Toxicology 4.4, 140-142.

Ahmed, R.G., 2 017d. Perinatal hypothyroidism and cytoskeleton dysfunction. Endocrinol Metab Syndr 6, 271. doi:10.4172/2161-1017.1000271

Ahmed, R.G., 2017e. Developmental thyroid diseases and monoaminergic dysfunction.Advances in Applied Science Research 8(3), 01-10.

Ahmed, R.G., 2017f. Hypothyroidism and brain development. J. Anim Res Nutr. 2(2), 13.

Ahmed, R.G., 2017g. Antiepileptic drugs and developmental neuroendocrine dysfunction: Every why has A Wherefore. Arch Med 9(6), 2.

Ahmed, R.G., 2017h. Gestational prooxidant-antioxidant imbalance may be at higher risk for postpartum thyroid disease. Endocrinol Metab Syndr 6, 279. doi:10.4172/2161-1017.1000279.

Ahmed, R.G., 2017i. Synergistic actions of thyroid-adipokines axis during development. Endocrinol Metab Syndr 6, 280.doi:10.4172/2161-1017.1000280.

Ahmed, R.G., 2017j. Thyroid-insulin dysfunction during development. International Journal of Research Studies in Zoology 3(4), 73-75. DOI: http://dx.doi.org/10.20431/2454-941X.0304010.

Ahmed, R.G., 2017k. Developmental thyroid diseases and cholinergic imbalance. International Journal of Research Studies in Zoology 3(4), 70-72. DOI: http://dx.doi.org/10.20431/2454-941X.0304009.

Ahmed, R.G., 2017l. Thyroid diseases and developmental adenosinergic imbalance. Int J ClinEndocrinol 1(2), 053-055.

Ahmed, R.G., 2017m. Maternal anticancer drugs and fetal neuroendocrine dysfunction in experimental animals. Endocrinol Metab Syndr 6, 281.doi:10.4172/2161-1017.1000281.

Ahmed, R.G., 2017n. Letter: Gestational dexamethasone may be at higher risk for thyroid disease developing peripartum. Open Journal Of Biomedical \& Life Sciences (Ojbili) 3(2), 01-06.

Ahmed, R.G., 2017o. Deiodinases and developmental hypothyroidism. EC Nutrition 11.5, 183-185.

Ahmed, R.G., 2017p. Maternofetal thyroid hormones and risk of diabetes. Int. J. of Res. Studies in Medical and Health Sciences 2(10), 18-21.

Ahmed, R.G., 2017r. Association between hypothyroidism and renal dysfunctions. International Journal of Research Studies in Medical and Health Sciences 2(11), 1-4. 
Dysfunction of Maternal Thyroid Hormones and Psychiatric Symptoms

Ahmed, R.G., 2017s. Maternal hypothyroidism and lung dysfunction. International Journal of Research Studies in Medical and Health Sciences 2(11), 8-11.

Ahmed, R.G., 2017t. Endocrine disruptors; possible mechanisms for inducing developmental disorders. International journal of basic science in medicine (IJBSM) 2(4), xx-xx. (in press)

Ahmed, R.G., 2017u. Maternal thyroid hormones trajectories and neonatal behavioral disorders. ARC Journal of Diabetes and Endocrinology 3(2), 18-21.

Ahmed, R.G., 2018a. Maternal hypothyroidism and neonatal testicular dysfunction. International Journal of Research Studies in Medical and Health Sciences 3(1), 8-12.

Ahmed, R.G., 2018b. Maternal thyroid disorders and bone maldevelopment: Are you ready to take risks for your off spring? J Pharma Pharma Sci (JPPS) in press. DOI: 10.29011/2574-7711. 100058.

Ahmed, R.G., Abdel-Latif, M., Ahmed F., 2015a. Protective effects of GM-CSF in experimental neonatal hypothyroidism. International Immunopharmacology 29, 538-543.

Ahmed, R.G., Abdel-Latif, M., Mahdi, E., El-Nesr, K., 2015b. Immune stimulation improves endocrine and neural fetal outcomes in a model of maternofetal thyrotoxicosis. Int. Immunopharmacol. 29, 714-721.

Ahmed, R.G., Davis, P.J., Davis, F.B., De Vito, P., Farias, R.N., Luly, P., Pedersen, J.Z., Incerpi, S., 2013a. Nongenomic actions of thyroid hormones: from basic research to clinical applications. An update. Immunology, Endocrine \& Metabolic Agents in Medicinal Chemistry, 13(1), 46-59.

Ahmed, R.G., El-Gareib, A.W. 2014. Lactating PTU exposure: I- Alters thyroid-neural axis in neonatal cerebellum. Eur. J. of Biol. and Medical Sci. Res. 2(1), 1-16.

Ahmed, R.G., El-Gareib, A.W., 2017. Maternal carbamazepine alters fetal neuroendocrine-cytokines axis. Toxicology 382, 59-66.

Ahmed, R.G., El-Gareib, A.W., Incerpi, S., 2014. Lactating PTU exposure: II- Alters thyroid-axis and prooxidant-antioxidant balance in neonatal cerebellum. Int. Res. J. of Natural Sciences 2(1), 1-20.

Ahmed, R.G., El-Gareib, A.W., Shaker, H.M., 2018a. Gestational 3, 3', 4, 4', 5-pentachlorobiphenyl (PCB 126) exposure disrupts fetoplacental unit: Fetal thyroid-cytokines dysfunction. Life Sciences 192, 213-220.

Ahmed, R.G., Incerpi, S., 2013. Gestational doxorubicin alters fetal thyroid-brain axis. Int. J. Devl. Neuroscience 31, 96-104.

Ahmed, R.G., Incerpi, S., Ahmed, F., Gaber, A., 2013b. The developmental and physiological interactions between free radicals and antioxidant: Effect of environmental pollutants. J. of Natural Sci. Res. 3(13), 74-110.

Ahmed, R.G.,Walaa G.H., Asmaa F.S., 2018b. Suppressive effects of neonatal bisphenol A on the neuroendocrine system. Toxicology and Industrial Health Journal (in press).

Awad, A.G., 2000. The thyroid and the mind and emotions/thyroid dysfunction and mental disorders. Thyrobulletin 7, 3.e1-3.e2.

Candelotti, E., De Vito, P., Ahmed, R.G., Luly, P., Davis, P.J., Pedersen, J.Z., Lin, H-Y., Incerpi, I., 2015. Thyroid hormones crosstalk with growth factors: Old facts and new hypotheses. Immun., Endoc. \& Metab. Agents in Med. Chem., 15, 71-85. 
Dysfunction of Maternal Thyroid Hormones and Psychiatric Symptoms

De Vito, P., Balducci, V., Leone, S., Percario, Z., Mangino, G., Davis, P.J., 2012. Nongenomic effects of thyroid hormones on the immune system cells: new targets, old players. Steroids 77, 988-995.

De Vito, P., Candelotti, E., Ahmed, R.G., Luly, P., Davis, P.J., Incerpi, S., Pedersen, J.Z., 2015. Role of thyroid hormones in insulin resistance and diabetes. Immun., Endoc. \& Metab. Agents in Med. Chem., 15, 86-93.

De Vito, P., Incerpi, S., Pedersen, J.Z., Luly, P., Davis, F.B., Davis, P.J., 2011. Thyroid hormones as modulators of immune activities at the cellular level. Thyroid 21, 879-890.

Demet, M.M., Ozmen, B., Deveci, A., Boyvada, S., Adigüzel, H., Aydemir, O., 2002. Depression and anxiety in hyperthyroidism. Arch. Med. Res. 33, 552-556.

Di Liegro, I., 2008. Thyroid hormones and the central nervous system of mammals (Review). Mol. Med. Rep. 1, 279-295.

Dugbartey, A.T., 1998. Neurocognitive aspects of hypothyroidism. Arch. Intern. Med. 158, 1413-1418.

Duntas, L.H., Maillis, A., 2013. Hypothyroidism and depression: salient aspects of pathogenesis and management. Minerva Endocrinol. 38, 365-377.

El-bakry, A.M., El-Ghareeb, A.W., Ahmed, R.G., 2010. Comparative study of the effects of experimentally-induced hypothyroidism and hyperthyroidism in some brain regions in albino rats. Int. J. Dev. Neurosci. 28, 371-389.

El-Ghareeb, A.A., El-Bakry, A.M., Ahmed, R.G., Gaber, A., 2016. Effects of zinc supplementation in neonatal hypothyroidism and cerebellar distortion induced by maternal carbimazole. Asian Journal of Applied Sciences 4(04), 1030-1040.

Goh, K.K., Chiu, Y.H., Shen, W.W., 2014. Hashimoto's encephalopathy mimicking presenile dementia. Gen. Hosp. Psychiatry 36, 360.e9-360.e11.

Henrichs, J., Bongers-Schokking, J.J., Schenk, J.J., Ghassabian, A., Schmidt, H.G., Visser, T.J., 2010. Maternal thyroid function during early pregnancy and cognitive functioning in early childhood: the generation R study. J. Clin. Endocrinol. Metab. 95, 4227-4234.

Incerpi, S., Hsieh, M-T., Lin, H-Y., Cheng, G-Y., De Vito, P., Fiore, A.M., Ahmed, R.G., Salvia, R., Candelotti, E., Leone, S., Luly, P., Pedersen, J.Z., Davis, F.B., Davis, P.J., 2014. Thyroid hormone inhibition in L6 myoblasts of IGF-I-mediated glucose uptake and proliferation: new roles for integrin $\alpha v \beta 3$. Am. J. Physiol. Cell Physiol. 307, C150-C161.

Kalmijn, S., Mehta, K.M., Pols, H.A., Hofman, A., Drexhage, H.A., Breteler, M.M., 2000. Subclinical hyperthyroidism and the risk of dementia. The Rotterdam study. Clin. Endocrinol. (Oxf) 53, 733-737.

Klecha, A.J., Barreiro Arcos, M.L., Frick, L., Genaro, A.M., Cremaschi, G., 2008. Immune-endocrine interactions in autoimmune thyroid diseases. Neuroimmunomodulation $15,68-75$.

Klecha, A.J., Genaro, A.M., Gorelik, G., Barreiro Arcos, M.L., Silberman, D.M., Schuman, M., 2006. Integrative study of hypothalamus-pituitarythyroid-immune system interaction: thyroid hormone-mediated modulation of lymphocyte activity through the protein kinase C signaling pathway. J. Endocrinol. 189, 45-55.

Klecha, A.J., Genaro, A.M., Lysionek, A.E., Caro, R.A., Coluccia, A.G., Cremaschi, G.A., 2000. Experimental evidence pointing to the bidirectional interaction between the immune system and the thyroid axis. Int. J. Immunopharmacol. 22, 491-500. 
Dysfunction of Maternal Thyroid Hormones and Psychiatric Symptoms

Mallett, P., Andrew, M., Hunter, C., Smith, J., Richards, C., Othman, S., 1995. Cognitive function, thyroid status and postpartum depression. Acta Psychiatr. Scand. 91, 243-246.

Noda, M., 2015. Possible role of glialcells in the relationship between thyroid dysfunction and mental disorders. Front. Cell. Neurosci. 9, 194.

Osterweil, D., Syndulko, K., Cohen, S.N., Pettler-Jennings, P.D., Hershman, J.M., Cummings, J.L., 1992. Cognitive function in non-demented older adults with hypothyroidism. J. Am. Geriatr. Soc. 40, 325-335.

Thompson, C.C., Potter, G.B., 2000. Thyroid hormone action in neural development. Cereb. Cortex 10, 939-945.

Van Herck, S.L.J., Geysens, S., Bald, E., Chwatko, G., Delezie, E., Dianati, E., Ahmed, R.G., Darras, V.M., 2013. Maternal transfer of methimazole and effects on thyroid hormone availability in embryonic tissues. Endocrinol. 218, 105-115.

Van Osch, L.A., Hogervorst, E., Combrinck, M., Smith, A.D., 2004. Low thyroid-stimulating hormone as an independent risk factor for Alzheimer disease. Neurology 62, 1967-1971.

Wijsman, L.W., de Craen, A.J., Trompet, S., Gussekloo, J., Stott, D.J., Rodondi, N., 2013. Subclinical thyroid dysfunction and cognitive decline in old age. PLoS One 8, e59199.

Citation: Ahmed R.G. "Dysfunction of Maternal Thyroid Hormones and Psychiatric Symptoms". American Research Journal of Endocrinology; 1(1): 31-36.

Copyright (C) Ahmed R.G., This is an open access article distributed under the Creative Commons Attribution License, which permits unrestricted use, distribution, and reproduction in any medium, provided the original work is properly cited. 